\title{
The Status of Woman in Islam
}

\author{
Etim E. Okon Ph.D \\ Senior Lecturer, Department of Religious and Cultural Studies, University Of Calabar, CRS, Nigeria
}

\begin{abstract}
The status of woman in Islam is a recurring theme in global feminist discourse. While there is a consensus that Islam has done much to improve the condition of woman compared to what was obtained in pre-Islamic Arabia- the Jahiliyya period, some scholars are worried over the conservative reinvigoration and perpetuation of medieval doctrines against women in the twenty-first century. The study shows that of all religions, Islam has been meticulous in preserving and defending the rights of woman. Since the intention of the study is not apologetic, but a critical reflection on problematic religious prescriptions, the study represents an advocacy for the abolition of doctrines and rules that are obnoxious and repugnant to natural justice. Islamic endorsement of plural marriage is unacceptable in the $21^{\text {st }}$ century. Whatever consideration and reasons that led Islam in medieval period to permit optional marriage of four women by one man, such reasons do not exist in modern society. This study recommends monogamous marriage for Islam. Passages on veiling and seclusion of woman and wife beating should be expunged from Islamic sacred books. While this may appear difficult, it is the opinion of this paper that Islam is in dire need of reforms to reposition it for global acceptance and participation in the $21^{\text {st }}$ century.

Keywords: Islam, women liberation, feminism, modernism, women's rights
\end{abstract}

\section{Introduction}

Traditional perception of the female and her role in Islamic societies are being challenged not only by radical feminism, but also by the undercurrent of modernism. The world has come of age, and all customary practices and religious beliefs that are repugnant to natural justice, equity and good conscience are being rejected. The international community more than ever, is now very sensitive to all issues that are related to women's human right. It is common knowledge that men in some societies subject women to slavish and atavistic control. Sometimes women are denied their inalienable, fundamental human rights through the forces of tradition and the legitimation of religion. A discussion on Islam and wom an can be fraught with the perils of exaggeration and oversimplification. The intention of this study is not to project Islam as having the worst record in women's human rights violations; rather it is our intention to carry out a comprehensive analysis using the tools of critical scholarship to unravel the strength and weakness of Islam in the treatment of women.

In many cultures of the world, women are victims of socio-cultural suppression. In their struggle for women's freedom, feminists have argued that the plight of women in modern society cannot be attributed to natural or biological factors. Feminists are convinced that women are not inferior to men, and that women's deplorable condition can rightly be attributed to social attitudes and perceptions. Sarah Delamont has defined feminism as "a desire for female self-determination" (1980:4). Feminists will want to see women accorded full freedom, respect, and recognition in socio-political dimensions. Feminism is an advocacy for autonomy and self-actualization for women in a male dominated society.

Women in pre-Islamic Arabia lived in misery and were victims of culturally approved discrimination, dehumanization and social deprivation. In Islamic history, the period before the advent of Prophet Muhammad is called the Jahiliyya period, which is interpreted as the period of ignorance. The Jahiliyya Arabs had a custom of burying their female children alive. It was an acceptable cultural practice for women to dance nude around the vicinity of Kaaba during the annual festival. One of the forms of marriage in pre-Islamic Arabia was by capture, women were captured and married by force without any resort to parental consent. It was Prophet Muhammad's social reforms that stopped such obnoxious criminal practices (Carmody and Carmody 1988: 251). Islam has done much to enhance the status of women more than any other world religion.

Historically, religion has contributed to the marginalization of women. Religion has provided the platform for male domination of society. As a social anesthesia, and a lullaby that soothes and assuages revolutionary tendencies and hinders rebellion, religion has consoled women to accept their fate as the will of God. This is a negative social function and a distortion of reality, which led Karl Marx to describe religion as: "The sigh of the oppressed creature, the heart of a heartless world, just as it is the opium of the 
people" $(1957: 38,39)$. Because of religious indoctrination, the superiority of men over women is taken for granted. Ancient philosophers in all their glories and intellectual prominence did virtually nothing to rescue womanhood from social humiliation; rather some of them aggravated the misery of women. Plato, an eminent philosopher of antiquity believed, and taught that a bad man's fate would be reincarnation as a woman (1929:91). For Aristotle females are mutilated males. "Females are imperfect males, accidentally produced by the father's inadequacy or by the malign influences of a moist south wind" (1943:175).

Apart from religion, patriarchal-tribal attitude has also influenced social perception of women. Pre-Islamic Arabia was prima facie a patriarchal society. That was the superstructure, which Islam inherited with minimal modifications. In Islam, a woman is a subordinate being which Allah' has graciously created for man's pleasure. Hedonism is endorsed and justified as a major determinant for the creation of woman. Islam recognizes human and civil rights of woman. It condemns cruel conduct against a woman by a man, and codifies women's property rights, and rights to collect and keep her dowry.

\section{Islam, Gender Justice and Equality}

Some Islamic scholars have exaggerated on the privileges and right which Islam has bestowed on woman. The prevailing view is that man and woman are equal, but that equality and sameness are two different ideas. To that extent Abdalati avers that "man and woman are not identical but they are created equals" (1975:184). He argues further that the Quran has not given to man dominant status over woman, nor was it Islam that introduced the question of whether, or not woman has any soul in her. Never in the history of Islam has any Muslim doubted the human status of woman, or her possession of soul and other fine spiritual qualities. Abdalati posited that Quran does not have pejorative description, or stereotype for woman and that in Islam, woman is not the product of the devil, or the seed of evil. Unlike other popular beliefs, Islam does not blame Eve alone for the first sin. The Quran makes it very clear that both Adam and Eve were tempted, that they both sinned; that God's pardon was granted to both after their repentance, and that God addressed them jointly (surah 2:35-36; 7:19,27: 20:117-123) (1975:184-185).

Islam does not accept the view that the creation of woman was a second thought, it recognizes the legitimate status of woman as man's equal partner in the procreation of mankind, " 0 mankind! Verily we have created you from a single (pair) of a male and a female, and made you into nations, tribes that you may know each other" (surah 49:13; 4:1). Equality of man and woman covers all aspects of human endeavors. Woman is equal to man in the quest for knowledge; she is entitled to freedom of speech, choice and association. Abdalati writes: "Islam grants woman equal rights to contract, to enterprise, to earn and posses independently. Her life, her property, her honor are sacred as those of man. If she commits any offense, her penalty is not less, or more than a man's in a similar case" (surah 2:178; 4:45, 92 93) (1975:187). Quran explicitly condemn people who discriminate against women as inferior, or sub-humans (surah 16:57-59, 62:42:47-50).

In the performance of religious rituals, woman is exempted from prayers and fasting during menstruation and periods of confinement. Woman is exempted from the obligatory prayers on Fridays. Generally, Islam exempt woman from all financial liabilities. Islam extols motherhood as a divine privilege and status of honor and admiration (surah 31:14-15; 46:15). Prophet Muhammad was emphatic when he declared that paradise is under the feet of mothers. As a rule, the mother is entitled to threefourths of the son's love and benevolence with only one-fourth given to the father. Abdalati expatiates more on the privileges which Islam has bestowed on woman. "As a wife she is entitled to demand of her prospective husband a suitable dowry that will be her own. She is entitled to complete provision and total maintenance by the husband. She does not have to work, or share with her husband the family expenses" (1975:189).

Another issue that has generated much argument among scholars is the practice of woman standing in prayers behind man. Abdalati has defended Islam on this, by saying that woman standing in an exclusive line during prayers can only be seen positively as a regulation for discipline and order and not classification of importance, “...Muslim prayers are not simply chanting or the sing-a-song type. They involve actions, motions, standing, bowing, prostration, etc. So if men mix with women in the same lines, it is possible that something disturbing, or distracting may happen" (1975:190).

The desire for gender justice and equality among human beings is universal. This seems to be the presupposition for a consensus "that all men are created equal..." as stated in the American Declaration of Independence in 1776 (qtd. in Stern 1975:163). Irrespective of this consensus, Stern is of the view that human equality is elusive. One of the sacred rights of citizens that were adopted by France's National Assembly in 1789 was that "All men are born free and equal in rights" (qtd. in Omoregbe 1994:82). Article 1 (3b) of the Charter of the United Nations which was adopted in 1945 states, inter alia that the world body will promote and encourage “... Respect for human rights and for fundamental freedoms for all without distinction as to race, sex, language, or religion" (qtd. in Reoch 
1994:265).

Article 1 of the Universal Declaration of Human Rights, which was adopted in 1948 states that "All human beings are born free and equal in dignity and rights" (qtd. in Reoch 1994:265). Gender equality can be seen presently as the genuine intention and aspiration of progressive and well-meaning humanity. It is yet to be accepted by many religions including Islam. In many parts of the world, women play second fiddle almost in everything. Some religious organizations have described the creation of women by God as a second thought. In Islam gender justice and equality is partially endorsed based on some of the prescriptions of the Holy Quran and the hadith of the Prophet. Surah 2:228 says "And men are a degree above them (women)". This particular verse is corroborated by surah 4:34: "Men are the protectors and maintainers of women because God has given the one more strength than the others".

The acceptable interpretation of surah 2:228 is that man is a step higher than the woman. The interpretation of surah 4:34 is that man is the protector of woman. It also connotes physical superiority of man over woman. Islam has allowed man to be in charge of woman. This is a situation, which Nijole Benokraitis has described as masculine paternalism and condescending chivalry which refers to superficially courteous behavior that is protective and paternalistic, but treats women as subordinates" (1989:226). While feminists have interpreted the two verses as a Quranic endorsement of permanent subjection of woman, Muslim apologists have insisted that there is no element of subjugation in the two verses, but that since Quran has given man the duty to care for woman, surah 4:34 is only applied in a family setting (Cragg 1985:152).

\section{The Veiling and Seclusion of Woman (Purdah)}

Islam has witnessed and tolerated the evolution of radical feminism which started with the publication of Qasim Amin's Tahriral-Mar'ah (The Liberation of Woman), and Al-Misriyyah (The Egyptian Woman) in 1899 which constituted an advocacy for the recognition of women's rights. Amin also advocated for women to be given a chance to obtain primary education and that law on polygamy and divorce should be revised. Leila Ahmed in her Women and Gender in Islam, has praised the passion of Amin paying the price for the liberation of women in Arab culture and society "changing customs regarding women and changing their costume, abolishing the veil in particular, were key, in the author's thesis" (1992:145).

This was followed by the movement for the unveiling of the Muslim woman which started in the mid-1920's, when the Egyptian feminist Hudu Sha'ra'wi pulled out her veil in protest against covering. It is also on record that Dora Shafig with a large number of feminists followers stormed the premises of Egyptian parliament and protested against the non-inclusion of women in the parliament (Cragg 1985:16). Even with all the struggles and the price which has been paid for women's liberation, it is observed sadly that "...Woman's status still largely depends on the biological fact that she is potentially, the bearer of children, whose care, at least in infancy, is usually her responsibility" (The New Encyclopaedia Britannica 1975:906).

In Islam, it is a tradition that woman is not allowed to expose herself to public view without modesty. The Holy Quran specifically directed that wives of Prophet Muhammad when speaking to other men should cover their bodies, for purposes of propriety (Smith 1989:342). Islam prohibited free mingling of the sexes so that the moral life of the nation can be preserved. Whenever there is need for woman to go out of their homes, they are expected to use simple dress and go out fully veiled. Both hands and faces are to be covered.

Woman is only allowed to unveil in a situation of genuine necessity and they have to put back the veil when the necessity has expired (Maududi 1960:170,171). Over the years, veils have taken a number of forms. There is a veil that covers the face from below the eyes down; there is another called chador, or burka, which covers the entire body, including the face, with a woven screen for sight (Smith 1989:343). The covering of ones body in Islam is called satr (cover). The purpose of covering is to encourage deep sense of purity and fidelity as a foundation of morality both in private and public life. Abdalati writes: "The veil which she must put on is one that can save her soul from weakness, her mind from indulgence, her eyes from lustful looks, and her personality from demoralization. Islam is most concerned with the integrity of woman, with the safeguarding of her morals and with the -protection of her character and personality" (Quran, 24: 3031) (1975:90-191).

Muslim feminists have argued convincingly that there is no verse in the Holy Quran that prescribes covering for women from head to toe. There is also an argument that the Quranic suggestion for wives of Prophet Muhammad to talk to other men behind a partition cannot in any way be applied as a general rule to all women in all ages. In many parts of the world, Muslim women are gradually unveiling themselves and embracing modernity with prudence. Covering of women in Islam is a clear picture of oppression and dehumanization in Western mentality. Some Muslim women are also careful so that it doesn't appear as if they are unveiling to embrace the dress code of the imperialist West.

\section{Woman and Islamic Marriage}


Marriage is an agreement between two adults of opposite sex to live together in a sexual relationship with the approval of their social group. It requires voluntary and matured consent. Marriage is intended to be a permanent bond of mutual loyalty and parity of dignity. Couples are expected to work hard to achieve unity and consensus. Marriage is not a servant-master relationship. The wife is neither a house attendant, nor a tenant to be expelled on flimsy excuses, which are rooted in human failure and shortcomings. The foregoing represents objective and universal expectations on marriage that transcends particularistic views of any religion and culture. Marriage in Arabic is called al-Nikah which means 'unity'. It is the foundation of human society. The outcome of marital relationship is the family; one of the most vital and indispensable social institutions that exist in every human society. The World Book Encyclopedia- says: "Family is oldest human institution. In many ways, it is the most important. It is society's most basic unit. Entire civilizations have survived, or disappeared, depending on whether family life was strong or weak" (qtd. in Watchtower, Making your Family 1978:6).

Marriage in Islam is not a sacrament, but a legal contract for life. Women are granted full rights under Islamic laws to negotiate and insist on favorable terms. A Muslim woman has the right to determine, collect and keep her dowry (mahr), as a source of personal pride and comfort. While the Holy Quran permits Muslim men to marry a maximum of four women, Muslim women are only allowed to marry only one man at a time. While Muslim men are allowed to marry Muslim women, Jews, or Christians, Muslim women can only marry a Muslim.

Marital unity in Islam is threefold: physical unity, spiritual unity, mental and emotional unity. Physical unity is realized through sexual oneness: "He (Allah) it is who created you from a single soul; and there from did make his mate that he might take rest in her" (surah 7: 189). Spiritual unity is achieved in studying the Holy Quran and the hadith together. Marital spirituality covers moments of worship and prayer in the house and in the Mosque. The highest spirituality of Islamic marriage is the equation of marriage with blood relationship. This is a wonderful idea, which is peculiar to Islam among all world religions: "And $\mathrm{He}$ (Allah) it is who has created man from the water and He has made him blood-relationship and marriage relationship" (surah 25:54).

Mental and emotional unity is achieved when there is mutuality, understanding, harmony and empathy in marital relationship: "They (your wives) are a garment for you, just as you are a garment for them" (surah 2:187).The Quranic metaphor which describes husband and wife as 'a garment' (libas) one to the other is an affirmation of marriage as a cure for loneliness, which every human being experiences. Since human life is an adventure in conflict and multiple betrayals, the purpose of Islamic marriage is to help couples cope with the stark realities of human existence. Allah has instituted marriage as a solution to anxiety, stress, depression and related neuro-psychological disorders. A. R. I. Doi comments on the Quranic metaphor of marriage as a garment: "The word garment also emphasizes the fact of their interdependence in life, the one being incomplete without the other... mutual upholding of each other's reputation and credit, mutual respect of one another's secrets, mutual affection, and mutual consolation in misfortunes" (The Cardinal Principles 1981:126).

Islam prohibits celibacy in all its ramifications. Marriage is meant to promote the moral and spiritual upliftment of society. Here we shall cite two hadiths to clarify the Islamic viewpoint on celibacy: "He who is able to marry should marry, for it keeps the eyes cast down and keeps a man chaste; and he who cannot, should take to fasting..." (qtd. in Doi, Cardinal Principles 1981:127). "Nikah (marriage) is my sunnah and he who abstains from my sunnah is not of me" (qtd. in Doi, Cardinal Principles 1981:127).

Plural marriage relationship in Islam is permissible in the Holy Quran. Surah 4:3 says: "If ye fear that ye cannot do justice with the orphans, then marry as it pleases you, two, three or four women: and if ye fear that ye cannot be equitable, then only one, or that your right hand possess (i.e. female slaves). That will be more suitable to prevent you from doing injustice". The interpretation of Surah 4:3 is that men are allowed to marry a maximum of four wives, if they have enough resources to provide for each equally. Contemporary exegesis has deviated from the traditional view. The verse is considered as a virtual prohibition because of the conditionality of fairness and equality of treatment, which is ideally unattainable (Cragg 1985: 152). But then what is equality of treatment? Equality in that verse may be interpreted to mean fairness and equity to all the wives and children. Kenneth Cragg has pointed out that: "There is nothing in the passage to check a husband who believes he can attain equality of treatment. He is left as the sole judge. If he fails, it will be a post facto failure and then the marriage exists"(1985:153).

With the resurgence of radical feminism in Moslem countries, plural marriage is fast becoming outdated. For instance, in Turkey and Tunisia, polygyny is illegal. In Iraq, municipal laws require the husband to obtain permission of the court before he can be allowed to marry more than one wife. In Egypt, the law requires the consent and approval of the first wife before the husband can take more than one wife. In Morocco and Lebanon, women have the right to extract a covenant with the husband that she will not accept a second wife (Smith 1989: 341). It is only reasonable and wise to expect that other Islamic countries will 
modify their marriage laws to reflect global endorsement of a monogamous union.

\section{Islam and Violence against Woman}

The Holy Quran has allowed man to use corporal punishment as a last resort to discipline erring woman. Wife battery is endorsed by the Quran: This is clearly stated in Surah 4:34 "...As for those, from whom you fear disobedience, admonish them and send them to beds apart and beat them". But this cannot be misunderstood as a license for irresponsible action against woman. In contemporary Islam, wife beating is being discouraged. Wife beating is an aspect of domestic violence, which is prohibited by municipal laws of many countries. The United Nations Declaration on the Elimination of Violence against Women has defined violence against women as: "....any act of gender-based violence that results in, or is likely to result in physical, sexual or mental harm or suffering to women, including threats of such acts, coercion or arbitrary deprivation of liberty, whether occurring in public or in private life" (qtd. in Awake 2001:4).

In international human rights and humanitarian law, violence against woman includes rape, assault, female infanticide, sexual harassment, sex tourism, forced pregnancy, compulsory heterosexuality, genital mutilation, sexual slavery, spousal rape, kidnapping of girls, forced prostitutions and selling of woman. Gender-based violence is a negation of the inalienable right of woman to possess and control her body.

Violence against woman is often tolerated and legitimated on historical and religious grounds, it is widespread, and cuts across ages and cultures. It has persisted despite repeated condemnation by the international community. The most recent action of the international community against gender-based violence was The Vienna Declaration that was adopted by representatives of 171 governments at the conclusion of the World Conference on Human Rights, $14^{\text {th }}$ June 1993, Article 3 (38) stresses: "The importance of working towards the elimination of violence against women in public and private life, the elimination of all forms of sexual harassment, exploitation and trafficking in women, the elimination of gender bias in the administration of justice" (qtd. in Reoch 1994:215).

\section{Islam, Sex and the Fall of Man}

According to Islamic tradition and jurisprudence, woman was created by God to be man's partner. Man and woman were created to achieve mutual correspondence and interdependence. In Islamic theology, woman is not the source of evil. Islam does not hold the view that Adam was tempted by Eve. The Quran teaches that Adam and Eve violated God's instruction against touching a certain tree and were expelled from paradise. Quran does not identify sexual intercourse as the act of disobedience, and does not in any way link the entire episode to the tree of knowledge. Al - Faruqi writes: "Islam regards sex as an innocent good and the pursuit of knowledge as a paramount duty, not as evil. Furthermore, the Quran adds that the disobedient act was repented and that God forgave its perpetrators...." (Quran 20:115) (1979:46).

$\mathrm{Al}$ - Faruqi avers that in Islam there is no "fall" and there is no resultant "original sin" hence the woman is innocent, a positive good, a consoler and a constant source of happiness and fulfillment to man and vice versa. "For Muslims, sex is as natural as food and drink, growth and death.... Indeed, sex is highly desirable. The Quran prohibits celibacy for the sake of God, and the prophet enabled marriage by making it his sunnah...." (Al - Faruqi 1979:46). Since the woman in Islam is not a property, but legal personality endowed with fundamental rights, sexual intercourse in marriage cannot be a random affair, but must be done with voluntary and passionate consent of the woman. Sexual promiscuity is condemned in Islam because it constitutes unfaithfulness and a breach of marital oath.

\section{Woman, Property Ownership and Inheritance in Islam}

Perhaps another landmark in Islamic theology and jurisprudence that favors woman is in the area of property ownership and inheritance. Woman has the right in Islamic inheritance law. She is given appropriate share in the deceased kin's property either as a wife, mother, sister or daughter. "This share is hers and no one can take it away or disinherit her. Even if the deceased wishes to deprive her by making a will to other relations or in favor of any other causes, the law will not allow him to do so" (Abdalati 1975:187). From the very beginning, Islam has always protected and recognized woman as autonomous legal personality endowed with civil rights. Ismail Al- Faruqi writes: "As a complete legal person the adult Muslim woman is granted title to keep her name forever. She has the right to acquire, keep and sell property as she pleases in perfect freedom. Her consent must be obtained for any transaction involving her," (1979:45).

The right of the woman to benefit equitably in the sharing of the deceased kin's property is affirmed in Islamic history and tradition. The portion that goes to the woman is determined by the degree of relationship to the deceased and the number and status of heirs. The Quranic prescription makes it impossible for anybody to disinherit a woman of her legitimate share in inheritance: "In the case of inheritance the question of equality and sameness is fully applicable in principle, both man and woman 
are equally entitled to inherit the property of the deceased relations but the portions they get may vary. In some instances man receives two shares whereas woman gets one only" (Abdalati 1975:187).

In Islamic law of evidence and civil procedures, two men or one is allowed to bear witness. The option for woman is limited to two before it can be authentic and admissible as evidence. Abdalati argues that this does not mean that the woman is inferior to man, but that it is a measure to secure and protect the rights of contractive parties, since woman in real life situation do not possess the skill, experience and versatility of man: "If a woman of the witness forgets something, the other one would remind her. Or if she makes an error, due to lack of experience, the other would help to correct her" (Abdalati 1975:189).

\section{Prophet Muhammad and Women}

It is glaring both from the Quran and the hadith that Prophet Muhammad had great and expansive love for women. This can be attested to by the following verses of the Quran and hadith: "... But deal kindly with them, for if ye hate them, it may happen that ye hate a thing wherein God hath placed much good" (Surah 4:10). Muhammad's love for women can be seen in the number of women, which he married. Muhammad's first marriage was with Khadija. From an initial monogamous union, Muhammad developed his marital life by adding more women.

Scholars are divided as to the actual number of Muhammad's wives. Gerhard Nehis and Walter Eric suggested thirteen women (1994:4), while Kenneth Boa put the number between ten to twelve (1986:51), J. J. Saunders put the number between ten or twelve (1965:35). Kenneth Cragg has observed that even though the number of Muhammad's wives far exceeded the maximum prescribed in (Surah 4:3), it is clearly stated in the Quran that it is not exemplary (1985:153).

Saunders notes that Muhammad's plural marriage was not in the lifetime of Khadija and that ".... majorities were widows whose husbands had fallen in his cause and for whom he might feel obliged to provide" (1965:35). Commenting further on Muhammad's erotic disposition, Saunders posits thus: "Yet his love of women is not denied by his biographers, and his personal preferences are artlessly revealed in the Quranic picture of a paradise where the pious faithfully are refreshed with delicious fruits and caressed by "hubris, black-eyed girls of eternal youth and beauty"' (1965:35).

The condition of widows generally in all cultures of the world is pathetic. Apart from alienation and hopelessness, there are other psychopathological consequences of bereavement, which the demise of the husband may cause a woman. Widows and their children live with a shattered psyche for a long time. Of all the problems associated with widowhood, economic burden is the most intimidating. It is the duty of the woman to care and provide for the children. In Hinduism, the woman is burnt alive during the cremation of her husband. In Islam, Prophet Muhammad did much from his magnanimity of spirit to uphold the cause of widows. In his lifetime, he assisted widows and their children and even married some of the widows. Widows are encouraged to remarry in Islam. Rendering help to a widow is considered one of the few things that pleases Allah: "One who makes efforts (to help) the widow, or a poor person is like a warrior (mujahid) in the path of Allah, or like one who stands up for prayer in the night, and fasts in the day" (Hadith: Bukhari 69, Hadith 1).

\section{Conclusion}

Progressive humanity should refuse to accept defeat in the struggle to liberate womanhood from all forms of degradation and atavistic fixation. The battle for women's liberation has raged for too long, the final victory is unlikely to be determined through a global consensus. It is expected that a negligible minority will rise up and mount intensive pressure for women's freedom. John Kennedy has rightly observed that... "In the long history of the world, only few generations have been granted the role of defending freedom in its hour of maximum danger" (qtd. in Philip Stern 1975:244).

What is desperately needed is a high degree of magnanimity and spirituality: magnanimity means rising above meanness, trivialities and self-interest. It means generosity of spirit and noble mindedness. In the words of H. M Tippett: "Magnanimity means greatness of spirit- a spirit not common to the natural heart. The natural heart is self -seeking, not self-effacing. To be magnanimous, then, means to be greater than one's natural self..." (qtd. in Hal Lingerman 1988:21). Spirituality does not necessarily mean spirit possession or ecstasy, it involves empathy and the courage to uphold the truth, no matter the consequences. C. Jinarajadasa has said: "To be spiritual is a matter of looking into the hearts of others, sharing their joys and anguishes, and feeling that you can strengthen the weak and purify the muddy and ugly places of the world" (qtd. in Lingerman 1988:33).

There is a misconception by some people that Islam is opposed to education. That is wrong. Islam is a religion with a rich intellectual tradition. There is no element of anti-intellectualism in Islamic doctrines. According to the, Holy Quran (Surah 96: 1), the first word that was revealed to 
Prophet Muhammad was the Arabic Igra, which means 'read'. The interpretation of that verse is that the first message of Allah to al-'Alamin (the inhabitants of the world), was to impart knowledge and understanding. Acquisition of knowledge is regarded in Islam as a meritorious act of worship (Ibadat). There are references both in the Quran and hadith where learning is praised, and the learned accorded preferential recognition and respect:

The superiority of the learned man over a (mere) worshipper is like the superiority of the moon when it is full over all the stars (Hadith: Tirmidhil Abu Da'ud and Ahmad Ibn Hanbal).

The learned (men) are the successors of the prophets. They leave behind knowledge as inheritance. One who inherits it obtains a great fortune (Hadith: Bukhari 3, Hadith 10)

It is unfortunate that even with all the encouragement, which the Quran and the hadith have given to education, Islamic womanhood faces serious deprivation and discrimination. The illiteracy level in most female Muslim population is high. Women are not allowed access to the educational opportunities that are available to men. Jane Smith has commented on the prevalent view, which hinders women in Islam from receiving functional education that could have aided sustainable development: "Until fairly recently, education for women in the Muslim world has been minimal. Girls were given the rudiment of an Islamic education, mainly a little instruction in the Quran and the traditions so as to be able to recite their prayers properly" (1989: 344, 345).

It is time for men to accept the plain truth that humankind consists of two sexes, which are equal, and at the same time different with infinite and unique diversity. A unilateral and sexually undifferentiated definition of what the world and humankind should be, without identifying the peculiar problems and needs of women is clearly an epistemic and logical error that should be corrected in the $21^{\text {st }}$ century. Islam has done much to liberate women from cultural and traditional inhibitions. The ulama should move fast to change the attitude of Muslims toward women. If Islam will lead other world religions (including Christianity), in working toward total freedom for womanhood, then there is need to invest in women. It is recommended that women education in Islamic countries should be free from primary school to university.

\section{References}

[1]. Abdalati, Hammudah (1975). Islam in Focus. American Trust Publications.

[2]. Ahmed, Leila (1992). Women and Gender in Islam. New Haven: Yale University Press.

[3]. Al Faruqi. Isma'il (1979). Islam. Illinois: Argus.

[4]. Aristotle (1943). The Generation of Animals. Leob Classical Library.

[5]. (Trans.) A. L. P London: Heinemann.

[6]. Awake, Help for Battered Women. Watchtower, November 8, 2001.

[7]. Benokraitis, N. V. (1989) "How Subtle Sex Discrimination Works". Seeing Ourselves: Classic, Contemporary, and Cross Cultural Readings in Sociology. John J. Macionis and Nijole V. Benokraitis (eds.). New Jersey: Prentice Hall.

[8]. Boa, Kenneth (1986). Cults, World Religions and You. Chicago: Victor Books.

[9]. Carmody, Denis L. and John Carmody (1988). The Story of World Religions. Mountain view, California: Mayfield.

[10]. Cragg, Kenneth (1985). The Call of the Minaret. Maryknoll: New York: Orbis Books.

[11]. Delamont, Sarah (1980). The Sociology of Women.London: Allen and Unwin.

[12]. Doi, A.R. I. (1981).The Cardinal Principles of Islam. Zaria: HudaHuda.

[13]. Lingerman, Hal (1988). A. Life Streams: Journeys into Meditation and Music, Wheaton: Quest Books.

[14]. Marx and Engels (1957). On Religion. Moscow: Progress Book.

[15]. Maududi, Abul'Ala (1960). Towards Understanding Islam. Riyah: WAMY Making Your Family Life Happy. New York: Watchtower, 1978.

[16]. Nehis, G. and Walter Eric (1994). Reach out: A Guide to Muslim Evangelism. Nairobi: Life Challenge.

[17]. Omoregbe, J. (1994). An Introduction to Philosophical Jurisprudence. Ikeja, Lagos: Joja Press.

[18]. Plato(1929).Timaeus: Leob Classical Library. (Trans.) R. G. Bury. London: Heinemann.

[19]. Reoch, Richard(1994). Human Rights: The New Consensus. London: Regency Press.

[20]. Saunders, J.J. (1965). A History of Medieval Islam. London: Routledge and Kegan Paul.

[21]. Smith, Jane I. (1989) "Women in Islam", in Seeing Ourselves: Classic, Contemporary and Cross-Cultural Readings in Sociology. John J. Macionis and Nijole V. Benokraritis (eds.). New Jersey: Prentice Hall.

[22]. Stern, Philip Van Doren (ed.) 1975. The Pocket Book of America. New York: Pocket Books.

[23]. "The Status of Women". The New Encyclopedia Britannica. Vol. 19 1975. 